\title{
Fat free mass index and fat mass index tracing on body composition chart in diabetes adolescent girls
}

\author{
Sochung Chung ${ }^{1,2^{*}}$, Hye Won Park ${ }^{1,2}$, Byung Ok Kwak', Kyo Sun Kim ${ }^{1,2}$ \\ From 8th APPES Biennial Scientific Meeting \\ Darwin, Australia. 29 October - 1 November 2014
}

\begin{abstract}
Aims
The prevalence of obesity and type 2 diabetes is increasing, and the impact of obesity on diabetes manifestation should be considered in management of type 1 diabetes children. There are some cases difficult to categorize into certain type in pediatric diabetic patients in the era of acceleration. The objective of this study was to determine the type differences of diabetes by analyzing the growth and body composition status and choose a proper treatment modality using the body composition chart.
\end{abstract}

\section{Methods}

Fourteen type 1 diabetic adolescent girls (age 12.6 \pm 3.3 years) and 16 type 2 diabetic adolescent girls (age $14.2 \pm 2.6$ years) were included. Height, weight and body compartment of fat mass, fat free mass were measured in each patient. Body mass index (BMI), fat mass index (FMI), fat free mass index (FFMI) and percent body fat (PBF) were calculated. FFMI and FMI were plotted on body composition chart and traced the coordinate during follow up period.

\section{Results}

BMI difference between diabetes types was explained with the difference in FFMI as well as FMI. Body composition chart presented that type 2 diabetes girls showed marked elevation in FMI and PBF. And FFMI was lower in type 1 diabetes girls. Superimposed effect of obesity on type 1 diabetes was expressed on body composition chart with marked increment of FMI and the adequate effect of lifestyle intervention in type 2

${ }^{1}$ Department of Pediatrics, Konkuk University Medical Center, Seoul, Korea Full list of author information is available at the end of the article diabetes was showed marked decrease in FMI and sustained FFMI during follow up period.

\section{Conclusion}

Body composition chart might be useful in adequate growth and glucose control monitoring in diabetes children and adolescents. Early adjustment of diabetes management strategy on the basis of body composition during growing period will improve glucose control and promote adequate growth.

\section{Authors' details}

${ }^{1}$ Department of Pediatrics, Konkuk University Medical Center, Seoul, Korea.

${ }^{2}$ Konkuk University School of Medicine, Seoul, Korea.

Published: 28 April 2015

doi:10.1186/1687-9856-2015-S1-P20

Cite this article as: Chung et al:: Fat free mass index and fat mass index tracing on body composition chart in diabetes adolescent girls. International Journal of Pediatric Endocrinology 2015 2015(Suppl 1):P20.

Submit your next manuscript to BioMed Central and take full advantage of:

- Convenient online submission

- Thorough peer review

- No space constraints or color figure charges

- Immediate publication on acceptance

- Inclusion in PubMed, CAS, Scopus and Google Scholar

- Research which is freely available for redistribution

Submit your manuscript at www.biomedcentral.com/submit
() Biomed Central 